\title{
Ethnic Conflict and Economic Disparity: Serbians and Albanians in Kosovo
}

\author{
Sumon Kumar Bhaumik \\ Centre for Economic Development and Institutions \\ Brunel University \\ Uxbridge, Middlesex UB8 3PH, United Kingdom \\ Sumon.Bhaumik@brunel.ac.uk \\ Ira N. Gang \\ Department of Economics, Rutgers University \\ New Brunswick, New Jersey 08901, USA \\ gang@economics.rutgers.edu \\ Myeong-Su Yun \\ Department of Economics, Tulane University \\ New Orleans, Louisiana 70118, USA \\ msyun@tulane.edu
}

This Version: July 10, 2006

Corresponding author:

Professor Ira N. Gang

Department of Economics

Rutgers University

75 Hamilton Street

New Brunswick, NJ 08901-1248

USA,

Phone: +1 (732) 932-7405

Fax: +1 (732) 932-7416

Email: gang@econ.rutgers.edu. 


\begin{abstract}
:
Using the Living Standards Measurement Study (LSMS) household survey from postconflict Kosovo we investigate the comparative economic well-being of Serbs and Albanians. An Oaxaca decomposition shows Serb households are both better endowed with income generating characteristics, such as education, and receive higher returns to these characteristics than Albanian households. Despite these advantages, Serb households have lower living standards, on average, than Albanian households. Most of the difference in living standards between Serb and Albanian households is on account of unobserved non-economic factors. This has serious implications for the political economy of policymaking in post-conflict Kosovo.
\end{abstract}

Keywords: consumption, ethnicity, decomposition

JEL Classifications: I32; O12; J15 


\section{Introduction}

In this paper, we examine the differential rates of economic achievement between ethnic Serbian and ethnic Albanian communities in the strife-torn United Nations (UN) protectorate of Kosovo. Serbs and Albanians in Kosovo were involved in an often bloody conflict in the 1990s as the Federal Republic of Yugoslavia ceased to exist as a political entity. Pavković (2000) argues that the animosity among ethnic groups manifested in this conflict can be traced back to at least the mid-nineteenth century. Poverty plagues the region and per-capita expenditure is low; actual or perceived ethnic differences fuel the tensions. Ethnic Serbs have lower income, measured by per-capita expenditure, and higher poverty incidence than ethnic Albanians. ${ }^{1}$ This observation runs counter to the popular perception that Serbs were the dominant political and economic force.

Both Serbs and Albanians can claim to be a minority group in the region. Of the estimated population of two million people in Kosovo in mid-2000, approximately $88 \%$ were Albanians and 7\% were Serbs according to Statistical Office of Kosovo (2003). However, of the total population of approximately 10.5 million people in Serbia and Montenegro, Kosovar Albanians account for only approximately $16 \%$ of this total. The current disparity in the ethnic composition of Kosovo is due to Serbian emigration and the high Albanian natural rate of population growth. The ethnic, religious, and social differences in Kosovo posed a challenge to the Yugoslav federation even before the country disintegrated in the 1990s. In 1974, Kosovo was granted autonomous status so that ethnic Albanians were allowed to develop their own institutions. However, this autonomous status was revoked in 1989 and, in response, Kosovo secessionists declared independence as a republic in July 1990. A civil war between Serbs and Albanians followed; this war was ended with military intervention by NATO. Kosovo is now an UN protectorate with a functioning 
administrative system.

Ethnic warfare was the focus of international concern in the late 1990s and has been studied thoroughly by social scientists interested in international relations, nationalism, religion, and social networks, e.g., Job (2002) and Pavković (2000). Whether economic disparity might also have provided fertile ground for ethnic conflict remains an open question. Unfortunately, without appropriate data, gauging differences in the economic welfare of ethnic groups during Kosovo's autonomous period and during its subsequent incorporation back into Serbia in the 1990s is difficult. We examine the living standards for Serbian and Albanian households using household survey data on 2,101 Albanian households and 416 Serbian households from the 2001 Living Standards Measurement Survey (LSMS) for Kosovo. The data show the degree of economic disparity after the war and during the UN intervention but they do not allow an estimation of the degree of economic disparity between Albanians and Serbs before the initiation of the war. However, since the future political process in Kosovo is likely to be influenced as much by the relative economic status of the Serbs and Albanians in the post-civil war period as by the memories of the war itself, an examination of the prevailing inter-ethnic differences in economic status is warranted.

We use per-capita expenditure as the measure of the economic well-being or standard of living. In the regression analysis, we explain the inter-household variations in living standards using characteristics of households and their constituent members, e.g., age, education, and wealth. Based on the regression estimates, we decompose the differences in living standards between Albanians and Serbs in Kosovo using Oaxaca-type algorithms to distinguish the amount of the gap that can be accounted for by differences in the level of household members 
characteristics, i.e., the characteristics effect, and by differences in the impact of the characteristics of household members, i.e., the coefficients effect.

Given the history of divisions along ethnic lines in the region, the relative roles of the level of the attributes the groups possess and the impact of these attributes on per-capita expenditures are important to identify. Such identification is useful to inform the choice of political and economic strategies in these early stages of Kosovo's reconstruction. If the characteristics effect explains the disparity, a policy aimed at reducing differences in household attributes is required. However, if the coefficients effect explains the disparity, a policy focusing on egalitarian treatment between the two ethnic groups is required. For example, if inter-ethnic differences in income and consumption are due primarily to differences in the stock of human capital measured by education, policymakers must devise a strategy that encourages the ethnic group with the smaller stock of per-capita human capital to obtain more education so as to narrow, and ultimately eliminate, this difference. However, if the differences in income and consumption arise because of differences in the rates of return on human capital, this would provide prima facie evidence that the labor market is discriminatory against one ethnic group and, therefore, policies to reduce or eliminate such discrimination are required.

Our results suggest that the relatively greater deprivation of the Serbian households in Kosovo is not explained by demographic characteristics, education, labor market behavior, wealth and assets, transfers, geography or the sectoral distribution of employment in terms of either the characteristics or the coefficients effect. Rather, these considerations that are found in traditional expenditure and poverty studies actually favor the Serbs so that policy-making for Kosovo is extremely difficult. Following the standard policy remedies, e.g., focusing on education, will not 
reduce the gap in economic achievement. To resolve divergence in the living standards of ethnic groups that are due mainly to differences in the returns on unobserved or non-economic household-level characteristics requires focusing on issues of equal treatment of different ethnic groups that are of paramount importance in strife-torn regions.

In Section 2, we describe the political and economic situation in Kosovo; in addition, we consider factors that may affect living standards. Section 3 contains a description of the LSMS data used in the empirical analysis and a comparison of the mean characteristics of the two ethnic groups. The empirical analyses consisting of ordinary least square (OLS) regressions to analyze the determinants of living standards among Albanians and Serbs and the decomposition of the difference in per-capita expenditure between the two ethnic groups based on methodology developed by Oaxaca (1973) are reported in Section 4. Finally, Section 5 discusses the implications of our empirical findings.

\section{Background Information and Living Standards}

Kosovo is a small landlocked territory that is part of the Balkan peninsula. Even prior to the changes in Central and Eastern Europe (CEE), people in Kosovo were poor by the standards of the region. In the year before Kosovo's autonomous status was revoked, i.e., 1988, per-capita output in Kosovo was only $28 \%$ of average per-capita output in Yugoslavia. Moreover, the economic crisis in Kosovo was aggravated during the period from 1991 to 2000 period because of ethnic conflict and the resultant civil war. The civil war reduced the number of able-bodied people of working age, damaged the housing stock and the utilities such as power and telecommunication, and disrupted the flow of commerce. Since 1999, Kosovo has been a 
protectorate under the guidelines of UN Security Council Resolution number 1244. The recovery of the economy soon after the end to the war was aided significantly by a reconstruction boom financed by international donors. By the second half of 2000, agricultural output was estimated to have reached $75 \%$ of its pre-conflict level, the investment-GDP ratio had climbed to almost $40 \%$, and per-capita GDP stood at 759 U.S. dollars. This recovery was marked by two major distortions, namely, total domestic consumption in 2000 was 146\% of GDP and imports accounted for approximately $80 \%$ of GDP.

The UN Mission in Kosovo (UNMIK) is responsible for Kosovo's administration, and has established institutions to support the process of economic re-invigoration. The UNMIK helped to create a Central Fiscal Authority (CSA); this authority implements tax policy and formulates an independent budget for Kosovo that is non-overlapping with the budgets of Serbia and Montenegro. Together the UNMIK and CSA established a new tax system and a tax administration to replace both the old system inherited from Yugoslavia and the parallel tax systems that had emerged during the conflict. The import regime was simplified and deregulated; no quantitative restrictions remain and the new tariff rate is a flat $10 \%$ for all goods and services. A Department of Reconstruction was created to coordinate donor assistance with public investments. Finally, the jobs of overseeing the payments system and domestic banks were entrusted to the newly created Banking and Payments Authority of Kosovo (BPAK).

The economic recovery continued through 2001 with Kosovo's 2001 per-capita GDP growing at a rate of $18.4 \%$. However, earlier imbalances persisted. For example, total consumption in 2001 was $121 \%$ of GDP, which is clearly unsustainable in the long run from a macroeconomic perspective. Moreover, despite the high consumption-to-GDP ratio, anecdotal 
evidence suggests that most Serbs and Albanians lived in poverty.

Several factors may have contributed to these low standards of living, and possible determinants of living standards are fairly stylized in the literature. For example, it has been argued that a household's per-capita expenditure decreases with its youth and old age dependency ratios, i.e., the proportion of household members in the age groups from 0 to 15 and greater than 65. The presence of young children and elderly people, whose employability and earning abilities are low, reduces the overall labor power of the household and, in some cases, working-age household members are not able to participate fully in the labor market because they are required to care for their children and the elderly members of the household, as Pezzin and Schone (1998) discuss. Even among working-age adults, the ability to participate effectively in the labor market may depend on age and gender, as Scott, Berger and Garen (1995) and Stanley and Jarrell (1998) suggest. In addition, households with female heads are likely to have lower incomes and expenditure levels, as Bhaumik and Nugent (1998) suggest, so that these households have a greater likelihood of being in poverty. Hence, we consider the average age of adults in the household and the proportion of working-age household members who are male to be important factors in determining the living standards of households.

The literature suggests that both employability and the returns on education can be significantly different for individuals having different levels of education, e.g., Grubb (1993), and Arum and Shavit (1995). To capture this effect, we include the proportion of working-age household members having different levels and types of education, namely, no formal education, primary education, general secondary education, vocational training, and tertiary or university education. Along with these characteristics of households, we consider the average number of 
weeks of labor or employment per household member per year, the proportion of adults in the households who are employed, and the proportion of households that have a working head. To the extent that the head of a household can transform his or her capabilities into employment and income, an unemployed head of a household reduces the return on the household's labor supply and, hence, the impact of the latter variable. In addition, in poorly performing economies, employment on family-owned farms and businesses may be an indication of disguised unemployment rather than entrepreneurship. Hence, a positive correlation may exist between employment on a family farm or business and per-capita expenditure or poverty status, as Mckinley and Alarcon (1995) suggest. Thus, we also consider the proportion of households that have working-age members employed in a family farm or business.

The wealth of a household may be an important determinant of its income and expenditure. In Kosovo, we measure the tangible wealth of households by the extent of their land ownership and the value of their livestock. These stocks are particularly relevant in a geographic region where markets were either disturbed or non-existent due to the prolonged military conflict because land and livestock contribute directly towards expenditure. Furthermore, we take into account social capital in the form of extended families and networks of friends who also contribute towards the economic well-being of a household. The literature on inter vivos transfers argues that such social capital plays a crucial role in expenditure smoothing both in developing and developed economies, as Bhaumik and Nugent (2000) discuss. Therefore, the proportion of households that receive private transfers from friends and extended family is an important factor to consider. In the same vein, public transfers may add to the well-being of the households but these two types of transfers should be treated differently because their marginal impacts on the 
expenditure of a household are different according to Maitra and Ray (2003). Hence, we also take account of the proportion of households that receives public support because of the disabilities of their adult members. However, the ownership of a disability card may reflect more the failing health of one or more adult household members, i.e., the health related capabilities of the households, rather than public transfers per se.

In Kosovo, the location of a household and whether or not it was uprooted from its place of origin may contribute significantly to its economic well-being or its economic deprivation. Geographical displacement brought about by war does not lead only to job loss and, subsequently, long term unemployment, but it can also disrupt established social networks. Because of the war, migration may not have been voluntary and migrants might have lost wealth. In addition, emigration out of the country may not have been distributed evenly among all income classes. Therefore, we include the proportion of households living in urban areas as well as proportion of households reporting having had to migrate from their place of origin after the disintegration of Yugoslavia. Considering all of these factors in our empirical analysis, we expect to find the following relationships. The per-capita expenditure of a household is likely to be higher if its youth dependency and old age dependency ratios are low, if the proportion of males among working-age adults is high, if the household head is male, if the proportion of educated workingage adults is high, if the household has a relatively large endowment of land and livestock, ${ }^{2}$ if the household receives public or private monetary or quasi-monetary transfers, if the household does not have a history of migration across regions, and if the household is located in an urban area.

\section{The Data}


To assess better the economic well-being of the population in Kosovo, including the width, depth, and correlates of poverty, the World Bank organized a Living Standards Measurement Survey (LSMS). The survey, which was carried out between September and December of 2000, collected data from 2,880 households and is statistically representative of both the Albanians and Serbs in Kosovo. After accounting for missing values, the survey provides information on 2,101 Albanian households and 416 Serbian households. ${ }^{3}$ In Table 1, we report per-capita expenditure for both communities. Albanian households have higher per-capita expenditure at $128.98 \mathrm{DM}$ versus $111.23 \mathrm{DM}$ for Serbian households. Despite the considerable difference in numbers of households, poverty incidence is high with $46 \%$ of Albanian households and $57 \%$ of Serbian households living below the poverty line. ${ }^{4}$ However, the average difference in the living standards of the poor and non-poor households is similar for the two communities. The ratio of the per-capita expenditure of the non-poor to poor households is 2.34 for Albanians and 2.25 for Serbs.

In Table 2, we report the results of three sets of t-tests using the descriptive statistics from Table 1. We test the null hypotheses that the means for variable $i$ are the same for the poor and non-poor households for each ethnic group in columns 1 and 2. We also test whether mean characteristics are different between Albanians and Serbs by considering all Albanians and all Serbs in column 3, only the non-poor Albanians and Serbs in column 4, and only the poor Albanians and Serbs in column 5. As reported in the table, the t-values associated with the hypotheses are mostly significant at the $1 \%$ level and they are largely consistent with our priors. We turn to some salient aspects of the data drawn from Tables 1 and 2 .

First, the youth dependency of Albanian households is nearly twice that of Serbian 
households but the opposite is true for old age dependency. In total, $28 \%$ of Serbian households and $36 \%$ of Albanian households are either in the age groups of 0 to 15 age or older than 65 . Among Albanian households, youth dependency is noticeably different between poor households at $36 \%$ and non-poor households at $29 \%$. However, among Serbian households, old age dependency is significantly different between poor households at $14 \%$ and non-poor households at $6 \%$. Second, more Albanian households at 9\% have no formal education compared with Serbian households at $3 \% .^{5}$ For both groups, the incidence of no formal education is noticeably higher among poor households, i.e., $12 \%$ for Albanians and $4 \%$ for Serbs, than among non-poor households, i.e., $7 \%$ for Albanians and $1 \%$ for Serbs. In addition, members of Albanian households are more likely to have primary education than are members of Serbian households. The proportions of household members with primary and secondary education, respectively, are $45 \%$ and $29 \%$ for Albanian households and 31\% and 51\% for Serbian households. Furthermore, a greater proportion of members of poor households in both ethnic communities have primary education, as opposed to secondary education, compared with non-poor households. No significant differences in the exposure of Albanian and Serbian households, nor of poor and nonpoor households, to vocational and tertiary education are found

Third, the age structure of households and the educational attainments of household members indicate that, on average, Serbian household members are older and more educated than members of Albanian households. Members of a Serbian household enjoy longer periods of employment annually at 20.64 weeks than do Albanian households at 16.20 weeks. In addition, members of poorer households work about 25 to $30 \%$ less than their counterparts in non-poor households in both communities, i.e., 12.82 versus 19.02 weeks for Albanians and 18.38 versus 
23.69 weeks for Serbs. This difference is consistent with the observation that more working-age adults of non-poor households, i.e., 47\% for Albanians and 51\% for Serbs, were employed at the time of the survey compared with the proportion of working-age adults in poor households, i.e., 34\% for Albanians and 43\% for Serbs. ${ }^{6}$ Fourth, Serbian households own much more land than do Albanian households with the size of land holdings at 120 acres and 70 acres, respectively. Interestingly, although we find no significant difference in the size of land holdings between poor and non-poor Albanian households, non-poor Serbian households own double the amount of land at 160 acres compared to the holdings of by poor Serbian households at 80 acres. $^{7}$

Fifth, although no difference exists in the incidence of ownership of disability cards among Albanian and Serbian households, the former are much more likely to receive private transfers. Indeed, only $5 \%$ of Serbian households receive private transfers compared with $44 \%$ of Albanian households, suggesting that children living in other countries are an important source of private transfers for Albanian households. However, access to disability and private transfers are not noticeably different across poor and non-poor households in either community. Finally, a considerably greater proportion of Albanian households at $76 \%$ migrated during the $1990 \mathrm{~s}$ compared with only $9 \%$ of Serbian households. The migration of Albanian households, mostly to the Former Yugoslav Republic of Macedonia, was precipitated by NATO's military intervention and the subsequent efforts by the Serbian military to gain control over Kosovo by expelling Albanians. ${ }^{8}$ However, no significant difference between the incidence of migration across poor and non-poor households is found for either ethnic group. Similarly, although Serbian households are more likely to be in urban areas than are the Albanian households at the time of the survey, i.e., $42 \%$ versus $28 \%$, we find little difference between the urban-rural distribution of poor and 
non-poor households.

As expected, these descriptive statistics show that poor households, on average, have lower capabilities, e.g., education, and smaller endowments, e.g., landholding, than non-poor households. Correspondingly, members of poor households work less than their counterparts in non-poor households. Hence, a significant portion of the variance in earnings or living standards across households is likely to be explained by differences in capabilities and endowments, i.e., differences in household characteristics. However, the reasons for the significantly lower percapita expenditure and the significantly greater incidence of poverty among Serbian households than among Albanian households, although the members of the former have age structures and educational attainments that are more consistent with higher earnings than those of the latter, remains to be addressed. Albanian households have almost certainly been assisted by the inflow of private transfers but private transfers alone are not likely to offset the disadvantages of Albanian households related to other characteristics. Indeed, these disadvantages are likely to have been reinforced by their predominantly rural locations and their need to migrate because of the conflict. The empirical issue to be investigated in the next section is whether the characteristics that favor the Serbs had a relatively muted impact on their earnings or living standards compared to the characteristics that favor the Albanians.

\section{The Factors Determining the Ethnic Differences in Living Standards}

To investigate the reasons why Serbs are more severely deprived than Albanians in Kosovo in terms of per-capita expenditure, we employ the decomposition analysis due to Oaxaca. Initially, we estimate the correlates of log per-capita expenditure using ordinary least squares 
(OLS) for Albanians and Serbs. Thereafter, we decompose the difference in mean per-capita expenditure of the two ethnic groups, highlighting the relative roles of differences in characteristics and coefficients in explaining the differences in living standards. First, we regress the logarithm of per-capita expenditure of the households in the sample on the characteristics that are likely to influence their earnings. To be consistent with our objective of decomposing the difference in the average per-capita expenditure of Serbian and Albanian households, we estimate separate regression models for each group.

Our common specification includes the age and gender structures of the households, the gender of the household head, the education attainment of the household members, the extent of labor market participation of household members, endowments measured by landholding and livestock ownership, public and private transfers, an indicator of whether or not the household migrated between the breaking up of Yugoslavia and the imposition of UNMIK governance structure in Kosovo, and an indicator of whether or not the household is located in an urban area. Furthermore, we add controls to account for the sector of employment of working-age adults. This specification borrows significantly from the literature on poverty, e.g., The World Bank (2001), the literature on Engel curves and consumption, e.g., Bhaumik and Nugent (1998), and the literature on labor supply and earnings, e.g., Dimova and Gang (2004). The coefficients and the robust standard errors of the OLS regressions are reported in Table 3. The F-statistics at 26.29 for Albanians and 7.88 for Serbs are both significant at the 1\% level. In addition, the adjusted Rsquare values of 0.24 for Albanians and 0.30 for Serbs are reasonable for cross-section regressions of these sample sizes. These statistics indicate that the specification is clearly a better fit for Serbian households. 
The coefficient estimates indicate that youth dependency has a negative impact on the living standards of both Albanian and Serbian households. In addition, the economic well-being of Albanian households is affected adversely by the presence of members who are 16 to 25 years old. However, the living standards of neither Albanian nor Serbian households are affected by the extent of their old age dependency. The result that the living standards of Albanian households are affected adversely if the head of the household is male is unusual. The literature on poverty, e.g., Dreze and Srinivasan (1997) suggests that the reverse is expected. However, the stylized fact that female-headed households are poorer than male-headed households is based on the observation that women, in general, are less likely to find (full time) employment than men and, on average, earn less than the latter. However, in periods of conflict, the circumstances may differ because the loss of industrial and agricultural jobs makes it equally likely for men and women to lose employment and potential earnings. Indeed, women may be more employable than men during such periods if they have a comparative advantage in occupations such as administrative and health care support. Hence, the result is not completely surprising for Kosovo.

Education has the predicted positive impact on household living standards for both communities. We emphasize two points. First, the impact of education on the living standards of households increases with the years of the education. For example, the coefficients of secondary education are 0.56 for the Albanian households and 0.88 for the Serbian households, while the coefficients for tertiary education are 0.73 and 1.41 , respectively. Second, the return to education is higher for the Serbian households. Since we have controlled for the sectoral distribution of the occupations of household members, this difference between Serbs and Albanians is not attributable to sectoral differences. 
Predictably, the employment status of the household head and the average numbers of weeks employed by the working-age adults has a positive impact on per-capita expenditure but only for Albanian households. These results are consistent with the descriptive statistics that exhibit greater differences among poor and non-poor Albanian households with respect to employment status than among poor and non-poor Serbian households. The coefficients also indicate that, although landownership does not affect the living standards of either community significantly, ownership of livestock improves the living standards of Albanian households. The magnitudes of the coefficients associated with these variables are small, however, especially in comparison with the variables that control for the youth dependency of the households and the educational level of the household members.

Finally, as expected, private transfers have a significant impact on the living standards of both Albanian and Serbian households. Private transfers offset to some extent the relative disadvantage of Albanian households due to their age structure and the human capital of adult members. Therefore, we compare the characteristics of Serbian and Albanian households that do and do not receive private transfers in Table 4. Regarding their labor market characteristics, Albanian households that do receive transfers are less likely to have a working head, i.e., 57\%, than households that do not receive transfers, i.e., $72 \%$, In addition, the working-age members of these households work only 13.54 weeks per year, on average, compared with their counterparts in the other households who work 18.27 weeks. In the Serbian households, private transfers compensate for a relative paucity of land and domestic animals in addition to these two differences. Although the source of private transfers for Serbs is not obvious, much of it almost certainly comes from outside Kosovo. The main source of private transfers for Albanian 
households is evidently children. About $36 \%$ of Albanian households that receive private transfers have children residing abroad while the corresponding figure for those households that do not receive transfers is $11 \%$. Most importantly, per-capita expenditure levels of the Albanian households that do and do not receive transfers are almost equivalent despite the fact that, on average, each adult member of households that do not receive private transfers are employed about $35 \%$ more per annum than their counterparts in households that receive private transfers. This result suggests that Albanian households use private transfers to offset the potentially adverse impact of poor labor market outcomes, which is consistent with the literature on private transfers, e.g., Altonji, Hayashi and Kotkikoff (1997).

To investigate the relative influences of the characteristics and the coefficients effects on the differences in the average level of monthly per-capita expenditure between the Albanian and Serbian communities, we use the stylized Oaxaca decomposition algorithm. ${ }^{9}$ The Oaxaca decomposition equation is written as:

$$
\bar{Y}_{A}-\bar{Y}_{B}=\left(\bar{X}_{A}-\bar{X}_{B}\right) \beta_{A}+\bar{X}_{B}\left(\beta_{A}-\beta_{B}\right)+\bar{e}_{A}-\bar{e}_{B},
$$

where $\bar{Y}_{j}$ and $\bar{X}_{j}$ are average log per-capita expenditure and a $1 \times K$ vector of average socioeconomic characteristics of group $j(A$ and $B)$, respectively, $\beta_{j}$ is a $K \times 1$ vector of parameters, $\bar{e}_{j}$ is an average error term that is zero by the construction of OLS. The first, second, and third components of the right-hand side of the equation are the characteristics, the coefficients and the residuals effects, respectively. The residuals effect is zero from OLS. The decomposition results 
based on the OLS estimates from Table 3 are reported in Table $5 .{ }^{10}$ As a reminder, the per-capita expenditure of an average Serbian household is 111.23DM and that of an average Albanian household is $128.29 \mathrm{DM}$. The difference in the logarithm of this measure of living standard between Serbian and Albanian households is -0.147 . The overall characteristics and coefficients effects from the decomposition analysis are 0.077 and $-0.224 \log$ points, respectively.

The positive value of the characteristics effect means that, if the Serbian and Albanian households were to have the same OLS coefficients, i.e., the impact of the characteristics on their living standards were identical, the logarithm of the per-capita expenditure of Serbs would have been higher than that of Albanians by 0.077 due solely to differences in characteristics. However, the coefficients effect of -0.224 implies that, if both Serbs and Albanians were to have the same characteristics so that any difference in living standards between the two ethnic groups would be due only to differences in the OLS coefficients, i.e., the rates of return on the characteristics, the logarithm of per-capita expenditure of Serbs would have been lower than that of Albanians by $0.224 \log$ points. In short, Serbs would be worse off if the differences between their characteristics and those of the Albanian households were to disappear. However, they would be better off in the absence of any differences between the two groups of households in the effectiveness of, or returns to, those characteristics. The former result is consistent with conventional wisdom and also the descriptive statistics reported in Table 1 that Serbs in Kosovo had more favorable characteristics, on average, than did Albanians. Although the latter result explains why Serbs have lower per-capita expenditures than Albanians despite having better characteristics, it requires further consideration.

In estimating the coefficients, estimates of the constant term are included and the 
coefficients effect generally incorporates the effect of the constant term. The coefficients of the constant terms explain the gap between Serbs and Albanians that is not attributed to controlling or explanatory variables. Hence, the difference in the constant terms may be interpreted as baseline differences between the two ethnic communities. ${ }^{11}$ We can separate the effect of the constant term from the effects of the other coefficients by rewriting (1) as:

$$
\bar{Y}_{A}-\bar{Y}_{B}=\sum_{k=1}^{K}\left(\bar{X}_{A}^{k}-\bar{X}_{B}^{k}\right) \beta_{A}^{k}+\left(\beta_{A}^{1}-\beta_{B}^{1}\right)+\sum_{k=2}^{K} \bar{X}_{B}^{k}\left(\beta_{A}^{k}-\beta_{B}^{k}\right)+\bar{e}_{A}-\bar{e}_{B},
$$

where $\beta_{j}^{1}$ is constant term for group $j(A$ and $B$ ). The result of this partitioning is reported in the second and third rows of Table 5. Both the characteristics effect and the coefficients effect of the controlling or explanatory variables favor the Serbs but the effect of the constant term favors Albanians overwhelmingly. If the characteristics of the Serbian and Albanian households and the returns on these measured characteristics for these two ethnic communities were to be equalized, the difference in the per-capita expenditures of these households would have been $-0.644 \log$ points because of the constant term alone making. Despite the Serbian advantage both in terms of measured characteristics and the returns on these characteristics, Serbs in Kosovo suffer more severe economic deprivation than Albanians because of the constant term in the regression specification.

We can decompose the characteristics and the coefficients effects into subgroups of variables or even individual variables. Disaggregating the characteristics effect, reported in Table 5, shows that equalizing demographic and educational characteristics of the Serbian and Albanian households would exacerbate the difference in per-capita expenditure that already exists between the two ethnic groups. In contrast, this gap would be reduced if Serbs were to receive the same 
support from extended families and other parts of the social network as do Albanians. Finally, differences in tangible assets such as land and livestock do not play a significant role in determining the difference in the average living standards of the two communities. These results are also largely consistent with the descriptive statistics.

Disaggregating the coefficients effect for the explanatory variables but not the constant term suggests that the gap in the per-capita expenditures between Serbian and Albanian households would be increased if the OLS coefficients, i.e., the rates of return on the characteristics, were equalized between the two ethnic groups. For example, the value of 0.272 $\log$ points for demographic characteristics implies that the returns to these characteristics favor Serbs considerably because the disparity that favors Albanians would have been greater if the differences in these coefficients were nullified. Similarly, Serbs are better off with the existing differences in the OLS coefficients for the education variables across the two communities. Given that these coefficients can be interpreted as returns on household characteristics, the results reported in Table 5 imply that Serbian households had an advantage over Albanian households in terms of both the characteristics and the coefficients effects. Furthermore, even though the proportion of Serb households receiving private transfers is substantially smaller than that for Albanian households, the impact of transfers on consumption is greater for the few Serbs households who receive them as demonstrated by the coefficients effect. Nonetheless, the Serbian advantages attributable to both the characteristics and the coefficients effects cannot overcome the baseline disparity that favors Albanians and is captured by the difference in the intercepts. 


\section{Conclusion}

Although the ethnic warfare in Kosovo was the center of international attention and the focus of the research of many social scientists in late 1990s, the literature does not address fully the issue of economic disparity between the ethnic Serbs and ethnic Albanians involved in the conflict. This omission is surprising as in 2001, contrary to popular perceptions, the incidence of poverty was higher among Serb households than among Albanian households. Using household survey data on Albanian and Serbian households from Living Standards Measurement Survey for Kosovo in 2001 and an Oaxaca decomposition, we examine the living standards for Serbian and Albanian households. Our analysis suggests that, in keeping with the popular wisdom about Kosovo's political economy, the characteristics and coefficients effects of economically meaningful variables largely favor Serb households. The lower incidence of poverty among Albanian households is partly on account of private transfers received by Albanian households, possibly from children living abroad. However, much of the difference in the average living standards between these two groups is explained by non-economic factors as captured by the constant terms in the underlying regression estimations.

The considerable size of the coefficients effect of the constant term, which more than compensates for the disadvantages Albanian households face with respect to the characteristics and coefficients effects, could be an artifact of model specification. Since the explanatory variables and the functional form used for the OLS analysis are the ones typically found to determine living standards of households, omitted variable bias is not likely to be a plausible explanation for this phenomenon. Furthermore, our decomposition results are robust to the choice of the omitted categories in the regression specification. Finally, the descriptive statistics have 
values that are consistent with our priors concerning the ethnic situation in Kosovo and the distinction between poor and non-poor households so that measurement issues should not pose a problem. Hence, ascribing the role played by the constant term in the decomposition analysis to limitations the included variables is inappropriate. Therefore, we must examine other factors to interpret the intercept in the decompositions.

Living standards in this strife-torn country are complicated by grey market activities, by smuggling and other illegal activities due to non-existent law enforcement, and by the policies of the international community, which has had a presence in Kosovo since 1999. Moreover, throughout this entire period, Serbs continued to move into enclaves making it difficult for them to generate high returns on their skills. In part, this retreat was out of fear of retribution but it may also have been the outcome of continued financial subsidies by the Milosevic government to the Serb community in Kosovo. Kostovicova and Bechev (2004) argue that such transfers precluded Serbs from accepting employment with the international forces in post-conflict Kosovo. Other reasons may be found for the origin of the disparity and the animosity between these two ethnic groups. Albanian autonomy from 1974 to 1989 and the consequences of UNMIK policies in postcivil war Kosovo may have been partially responsible.

Irrespective of the exact reason for the favorable impact of non-economic (or unobserved) factors on the living standards of Albanian households, the incongruity between the favorable characteristics and coefficients effects for the Serbs and the higher average living standards of the Albanians poses a challenge for bringing political normalcy back to Kosovo, as a precursor to economic prosperity. For political normalcy to return to Kosovo, both the Serbian and the Albanian communities must feel that they are equals on economic terms as well as in the political 
arena. To the extent that Serb households have better attributes (i.e., favorable characteristics effects) and higher returns on these attributes (i.e., favorable coefficients effects), the Albanian community would seek redress in the form of economic parity. At the same time, however, to the extent that Serb households have lower living standards despite having more favorable characteristics and more favorable returns on these characteristics, the Serbs would perceive discrimination, especially in the aftermath of a separation of Kosovo from Serbia, and seek redress in the form of a level economic playing field. If both communities nurse feelings of discrimination and persecution, fruitful political dialogue that must precede concrete policy decisions will be at a premium, and this, in turn, will pose a serious dilemma for the international community that is seeking to provide a functional governance structure in Kosovo. At the very least, therefore, any debate about future economic policies in Kosovo will have to overcome the inhibitions associated with political correctness, and be accompanied by a full discussion of the facts and figures associated with differences in living standards of the two ethnic groups that have long been at war with each other. 


\section{REFERENCES}

Altonji, Joseph G., Hayashi, Fumio, Kotlikoff, Laurence, 1997. Parental altruism and inter vivos transfers: Theory and evidence. Journal of Political Economy 105, 1121-1166.

Arum, Richard, Shavit, Yossi, 1995. Secondary vocational education and the transition from school to work. Sociology of Education 68, 187-204.

Bhaumik, Sumon K., Nugent, Jeffrey B., 1998. An analysis of food demand in Peru: Implications for food-feed competition. Review of Development Economics 3, 242-257.

Bhaumik, Sumon K., Nugent, Jeffrey B., 2000. Wealth accumulation, fertility, and transfers to elderly households in Peru. In: Mason, Andrew, Tapinos, George (Eds.), Sharing the Wealth, Oxford University Press, New York, pp. 256-281.

Blinder, Alan S., 1973. Wage discrimination: Reduced form and structural estimates. Journal of Human Resources 8, 436-455.

Buvinic, Mayra, Gupta, Geeta R., 2001. Female-headed households and female-maintained families: Are they worth targeting to reduce poverty in developing countries? Economic Development and Cultural Change 45, 259-280.

Dimova, Ralitza, Gang, Ira N., 2004. Self-selection and earnings during volatile transition. Discussion Paper No. 1158. IZA - Institute for the Study of Labour, Bonn, Germany.

Dreze, Jean, Srinivasan, P.V., 1997. Widowhood and poverty in rural India: Some inferences from household survey data. Journal of Development Economics 54, 217-234.

Grubb, W. Norton, 1993. The varied economic returns to postsecondary education: New evidence from the class of 1972. Journal of Human Resources 28, 365-382.

Job, Cvijeto, 2002. Yugoslavia's ruin. Rowman \& Littlefield Publishers, New York, NY. 
Kostovicova, Denisa D., Bechev, Dimitar, 2004. Kosovo: Successes and failures of international civil and military involvement. Discussion Paper No. 31. Centre for the Study of Global Governance, London School of Economics and Political Science, London, UK.

Maitra, Pushkar, Ray, Ranjan, 2003. The effect of transfers on household expenditure patterns and poverty in South Africa. Journal of Development Economics 71, 23-49.

Mckinley, Terry, Alarcon, Diana, 1995. The prevalence of rural poverty in Mexico. World Development 23, 1575-1585.

Moene, Karl O., 1992. Poverty and landownership. American Economic Review 82, 52-64.

Oaxaca, Ronald L., 1973. Male-female differentials in urban labor markets. International Economic Review 14, 693-709.

Oaxaca, Ronald L., Ransom, Michael R., 1998. Calculation of approximate variances for wage decomposition differentials. Journal of Economic and Social Measurement 24, 55-61.

Oaxaca, Ronald L., Ransom, Michael R., 1999. Identification in detailed wage decompositions. Review of Economics and Statistics 81, 154-157.

Pavković, Aleksandar, 2000. The Fragmentation of Yugoslavia: Nationalism and War in the Balkans, 2nd edition. St. Martin's Press, New York, NY.

Pezzin, Liliana E., Schone, Barbara S., 1998. Intergenerational household formation, female labor supply and informal care giving. Journal of Human Resources 34, 475-503.

Scott, Frank A., Berger, Mark C., Garen, John E., 1995. Do health insurance and pension costs reduce the job opportunities of older workers? Industrial and Labor Relations Review $\mathbf{4 8 ,}$ 775-791.

Stanley, T.D., Jarrell, Stephen B., 1998. Gender wage discrimination bias? A meta-regression 
analysis. Journal of Human Resources 33, 947-973.

Statistical Office of Kosovo, 2003, Kosovo and its population. Available at http://www.ksgov.net/esk/index_english.htm, Kosovo.

World Bank (2001), "Kosovo: Poverty Assessment," 2 volumes, Report No. 23390-KOS, Washington, DC.

Yun, Myeong-Su, 2005. Hypothesis tests when decomposing differences in the first moment. Journal of Economic and Social Measurement 30, 295-304. 
Table 1

Characteristics of the Households

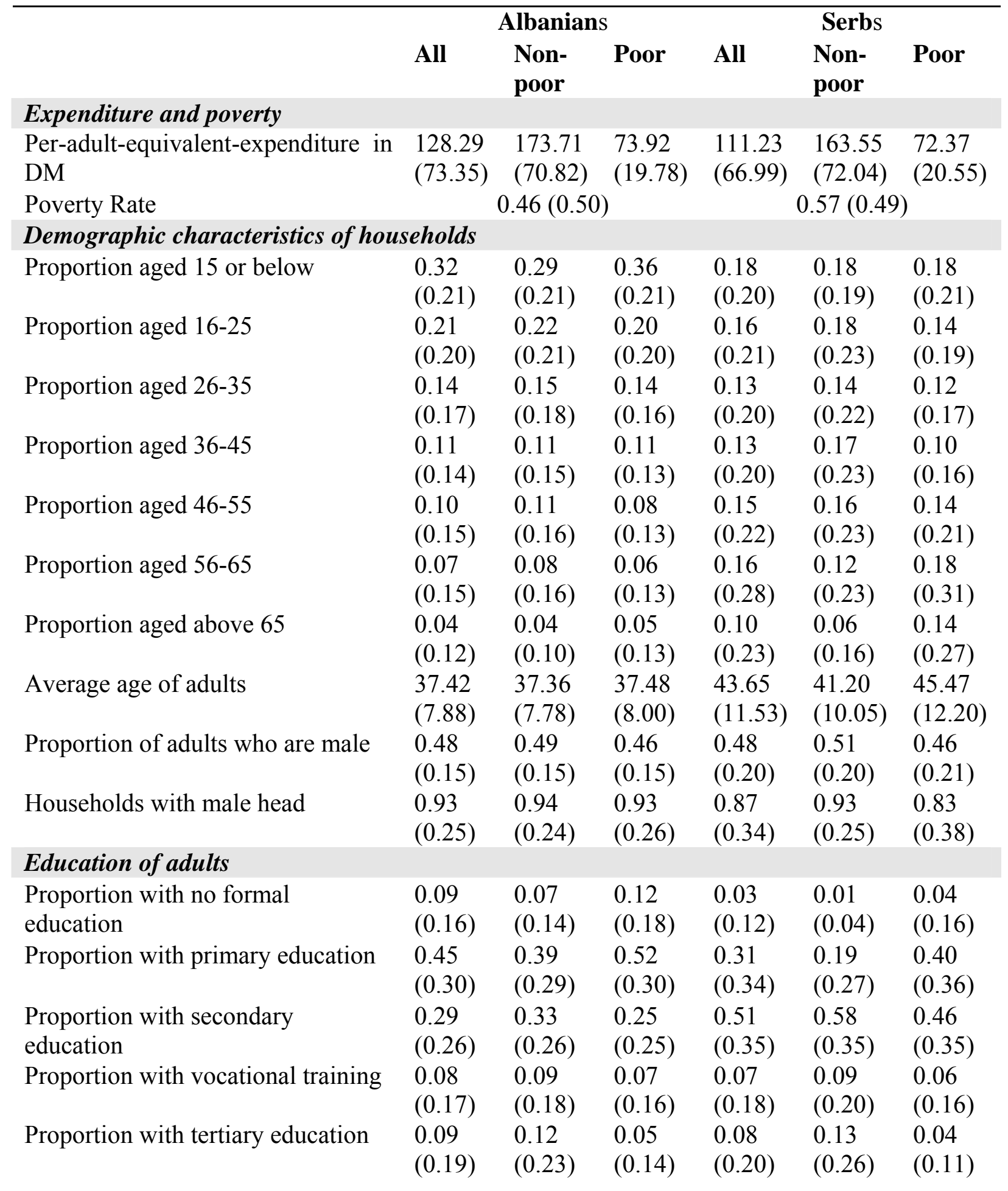


Table 1 continued

$\begin{array}{llllll}\text { All } & \begin{array}{c}\text { Albanians } \\ \text { Non- } \\ \text { poor }\end{array} & \text { Poor } & \text { All } & \begin{array}{c}\text { Serbs } \\ \text { Non- } \\ \text { poor }\end{array} & \text { Poor } \\ & & & & & \\ 16.20 & 19.02 & 12.82 & 20.64 & 23.69 & 18.38 \\ (13.03) & (13.10) & (12.12) & (18.32) & (18.11) & (18.16) \\ 0.41 & 0.47 & 0.34 & 0.47 & 0.51 & 0.43 \\ (0.29) & (0.28) & (0.28) & (0.38) & (0.37) & (0.39) \\ 0.65 & 0.72 & 0.57 & 0.61 & 0.66 & 0.57 \\ (0.48) & (0.45) & (0.50) & (0.49) & (0.47) & (0.49) \\ 0.27 & 0.29 & 0.24 & 0.34 & 0.33 & 0.34 \\ (0.28) & (0.29) & (0.28) & (0.40) & (0.39) & (0.40) \\ & & & & & \end{array}$

\section{Labor market characteristics}

Average number of weeks of labor

per household member per year

Proportion of working adults

2.82

18.38

Household with working head
Proportion of households with
members working in family farms
\& businesses

Wealth/Assets

Acreage of land household owns

$\begin{array}{llllll}0.07 & 0.07 & 0.07 & 0.12 & 0.16 & 0.08\end{array}$

(000)

$\begin{array}{llllll}(0.10) & (0.10) & (0.09) & (0.62) & (0.93) & (0.13)\end{array}$

Value of animals household owns

0.56

0.57

0.55

0.46

0.39

0.51

(000 DM)

$(0.78) \quad(0.81) \quad(0.73)$

$(0.75)$

$(0.73)$

$(0.76)$

\section{Transfers}

Households at least one of whose

$\begin{array}{llllll}0.10 & 0.09 & 0.12 & 0.10 & 0.08 & 0.11\end{array}$

members has a disability card

$(0.30)-(0.28)$

(0.32)

$(0.30) \quad(0.28)$

$(0.32)$

Household at least one of whose

0.44

0.44

0.43

0.05

0.06

0.04

members receive private transfers

$(0.50)$

(0.50)

$(0.50)$

$(0.21) \quad(0.23)$

(0.19)

\section{Geographic characteristics}

Households that migrated from

another region

$0.76 \quad 0.75$

0.77

0.09

0.09

0.09

Urban households

$$
\text { (0.43) }
$$

$(0.43)$

$(0.42)$

$(0.29)$

$(0.28)$

$(0.29)$

0.28

0.31

0.24

0.42

0.44

0.40

Number of households

$\begin{array}{lll}(0.40) & (0.41) & (0.38)\end{array}$

$(0.49)$

$(0.49)$

$(0.49)$

2101

1136

965

416

180

236

Source: LSMS, author's own calculation.

Notes: The figures within the parentheses are standard deviations. 
Table 2

T-tests for Differences in Characteristics of the Households

\begin{tabular}{|c|c|c|c|c|c|}
\hline & \multicolumn{2}{|c|}{ Poor vs. Non-Poor } & \multicolumn{3}{|c|}{ Albanians vs. Serbs } \\
\hline & Albanians & Serbs & All & $\begin{array}{l}\text { Among } \\
\text { Non-Poor }\end{array}$ & $\begin{array}{l}\text { Among } \\
\text { Poor }\end{array}$ \\
\hline Per-adult-equivalent-expenditure (DM) & $* * *$ & $* * *$ & $* * *$ & - & - \\
\hline Poverty rate & NA & NA & $* * *$ & NA & NA \\
\hline \multicolumn{6}{|l|}{ Demographic characteristics of Households } \\
\hline Proportion aged 15 or below & $* * *$ & - & $* * *$ & $* * *$ & $* * *$ \\
\hline Proportion aged $16-25$ & $* * *$ & $*$ & $* * *$ & $* *$ & $* * *$ \\
\hline Proportion aged $26-35$ & - & - & - & - & - \\
\hline Proportion aged $36-45$ & - & $* * *$ & $* * *$ & $* * *$ & - \\
\hline Proportion aged $46-55$ & $* * *$ & - & $* * *$ & $* * *$ & $* * *$ \\
\hline Proportion aged $56-65$ & $* * *$ & $* *$ & $* * *$ & $* *$ & $* * *$ \\
\hline Proportion with adults above 65 & $* * *$ & $* * *$ & $* * *$ & $*$ & $* * *$ \\
\hline Average age of adults & - & $* * *$ & $* * *$ & $* * *$ & $* * *$ \\
\hline Proportion of adults who are male & $* * *$ & $* * *$ & - & $*$ & - \\
\hline Households with male head & - & $* * *$ & $* * *$ & - & $* * *$ \\
\hline \multicolumn{6}{|l|}{ Education of Adults in Household } \\
\hline Proportion with no formal education & $* * *$ & $* * *$ & $* * *$ & $* * *$ & $* * *$ \\
\hline Proportion with primary education & $* * *$ & $* * *$ & $* * *$ & $* * *$ & $* * *$ \\
\hline Proportion with secondary education & $* * *$ & $* * *$ & $* * *$ & $* * *$ & $* * *$ \\
\hline Proportion with vocational training & $* * *$ & $*$ & - & - & - \\
\hline Proportion with tertiary education & $* * *$ & $* * *$ & - & - & - \\
\hline \multicolumn{6}{|l|}{ Labor market characteristics } \\
\hline $\begin{array}{l}\text { Average number of weeks of labor per household } \\
\text { member per year }\end{array}$ & $* * *$ & $* * *$ & $* * *$ & $* * *$ & $* * *$ \\
\hline Proportion of working adults & $* * *$ & $* *$ & $* * *$ & $*$ & $* * *$ \\
\hline Household with working head & $* * *$ & $*$ & - & - & - \\
\hline $\begin{array}{l}\text { Proportion of households with members } \\
\text { working in family farms \& businesses }\end{array}$ & $* * *$ & - & $* * *$ & - & $* * *$ \\
\hline \multicolumn{6}{|l|}{ Wealth and non-wage income } \\
\hline Acreage of land household owns (000) & - & - & $* * *$ & $* * *$ & - \\
\hline Value of animals household owns (000 DM) & - & - & $* *$ & $* *$ & - \\
\hline \multicolumn{6}{|l|}{ Transfers } \\
\hline $\begin{array}{l}\text { Households at least one of whose members has } \\
\text { a disability card }\end{array}$ & $* *$ & - & - & - & - \\
\hline $\begin{array}{l}\text { Household at least one of whose members } \\
\text { receive private transfers }\end{array}$ & - & - & $* * *$ & $* * *$ & $* * *$ \\
\hline \multicolumn{6}{|l|}{ Geographic Characteristics } \\
\hline Households that migrated from another region & - & - & $* * *$ & $* * *$ & $* * *$ \\
\hline Urban households & $* * *$ & - & $* * *$ & $* * *$ & $* * *$ \\
\hline
\end{tabular}


Notes:

i. The symbols $*, * *$ and $* * *$ indicate significance at the $10 \%, 5 \%$ and $1 \%$ levels, respectively.

ii. The comparison in column 1 is between poor and non-poor Albanian households.

iii. The comparison in column 2 is between poor and non-poor Serbian households.

iv. The comparison in column 3 is between Albanians and Serbs.

v. The comparison in column 4 is between non-poor Albanians and Serbs.

vi. The comparison in column 5 is between poor Albanians and Serbs. 
Table 3

Determinants of Per-Capita Expenditure of Albanians and Serbs: OLS Estimation

\begin{tabular}{|c|c|c|c|c|}
\hline \multirow[b]{2}{*}{ Constant } & \multicolumn{2}{|c|}{ Albanians } & \multicolumn{2}{|c|}{ Serbs } \\
\hline & $\begin{array}{l}\text { Estimate } \\
4.36 * * *\end{array}$ & $\begin{array}{l}\text { S.E. } \\
(0.11)\end{array}$ & $\begin{array}{l}\text { Estimate } \\
3.72 * * *\end{array}$ & $\begin{array}{l}\text { S.E. } \\
(0.23)\end{array}$ \\
\hline \multicolumn{5}{|l|}{ Demographic characteristics of households } \\
\hline Proportion aged 15 or below & $-0.65 * * *$ & $(0.10)$ & $-0.35 *$ & $(0.21)$ \\
\hline Proportion aged $16-25$ & $-0.20 * *$ & $(0.09)$ & -0.16 & $(0.17)$ \\
\hline Proportion aged $36-45$ & -0.01 & $(0.09)$ & 0.10 & $(0.15)$ \\
\hline Proportion aged $46-55$ & 0.10 & $(0.10)$ & -0.08 & $(0.16)$ \\
\hline Proportion aged $56-65$ & 0.10 & $(0.12)$ & -0.17 & $(0.18)$ \\
\hline Proportion aged above 65 & -0.11 & $(0.13)$ & -0.19 & $(0.16)$ \\
\hline Proportion of adults who are male & 0.09 & $(0.09)$ & 0.15 & $(0.16)$ \\
\hline Households with male head & $-0.11 * *$ & $(0.05)$ & 0.07 & $(0.09)$ \\
\hline \multicolumn{5}{|l|}{ Education } \\
\hline Proportion of adults with primary education & $0.20 * * *$ & $(0.08)$ & $0.32 *$ & $(0.19)$ \\
\hline Proportion of adults with secondary education & $0.56^{* * *}$ & $(0.08)$ & $0.88 * * *$ & $(0.20)$ \\
\hline Proportion of adults with vocational training & $0.46^{* * *}$ & $(0.10)$ & $0.80 * * *$ & $(0.23)$ \\
\hline Proportion of adults with tertiary education & $0.73 * * *$ & $(0.10)$ & $1.41 * * *$ & $(0.22)$ \\
\hline \multicolumn{5}{|l|}{ Labor market characteristics } \\
\hline $\begin{array}{l}\text { Average number of weeks of labor per } \\
\text { household member per year }\end{array}$ & $0.00 * *$ & $(0.00)$ & 0.00 & $(0.00)$ \\
\hline Proportion of working adults & 0.08 & $(0.11)$ & -0.20 & $(0.21)$ \\
\hline Household with working head & $0.07 * *$ & $(0.03)$ & 0.04 & $(0.07)$ \\
\hline $\begin{array}{l}\text { Proportion of households with members } \\
\text { working in family farms \& businesses }\end{array}$ & 0.04 & $(0.07)$ & 0.14 & $(0.13)$ \\
\hline \multicolumn{5}{|l|}{ Wealth/Assets } \\
\hline Acreage of land household owns (000) & 0.20 & $(0.15)$ & 0.01 & $(0.01)$ \\
\hline Value of animals household owns (000 DM) & $0.04 * *$ & $(0.02)$ & 0.04 & $(0.03)$ \\
\hline \multicolumn{5}{|l|}{ Transfers } \\
\hline $\begin{array}{l}\text { Households at least one of whose members } \\
\text { has a disability card }\end{array}$ & 0.03 & $(0.04)$ & -0.09 & $(0.07)$ \\
\hline $\begin{array}{l}\text { Household at least one of whose members } \\
\text { receive private transfers }\end{array}$ & $0.10 * * *$ & $(0.02)$ & $0.33 * * *$ & $(0.11)$ \\
\hline \multicolumn{5}{|l|}{ Geographic Characteristics } \\
\hline Households that migrated from another region & 0.00 & $(0.03)$ & -0.09 & $(0.07)$ \\
\hline Urban households & 0.02 & $(0.03)$ & 0.05 & $(0.06)$ \\
\hline F-Statistics & \multicolumn{2}{|c|}{$26.29 * * *$} & \multicolumn{2}{|c|}{$7.88 * * *$} \\
\hline Adjusted R-square & \multicolumn{2}{|c|}{0.24} & \multicolumn{2}{|c|}{0.30} \\
\hline Number of households & \multicolumn{2}{|c|}{2101} & \multicolumn{2}{|c|}{416} \\
\hline
\end{tabular}


Notes:

i. The symbols *,** and $* * *$ indicate significance at the $10 \%, 5 \%$ and $1 \%$ levels, respectively.

ii. Weights have been used for the estimation.

iii. The reported standard errors are robust to misspecification.

iv. We have also controlled for the sectors of employment of the household members. 
Table 4

Characteristics of the Households by Private Transfer

\begin{tabular}{|c|c|c|c|c|c|c|}
\hline & \multicolumn{3}{|c|}{ Albanians } & \multicolumn{3}{|c|}{ Serbs } \\
\hline & All & Yes & No & All & Yes & No \\
\hline $\begin{array}{l}\text { Household at least one of whose } \\
\text { members receive private transfers }\end{array}$ & $\begin{array}{l}0.44 \\
(0.50)\end{array}$ & & & $\begin{array}{l}0.05 \\
(0.21)\end{array}$ & & \\
\hline \multicolumn{7}{|l|}{ Expenditure and poverty } \\
\hline $\begin{array}{l}\text { Per adult equivalent expenditure } \\
\text { (DM) }\end{array}$ & $\begin{array}{l}128.29 \\
(73.35)\end{array}$ & $\begin{array}{l}129.01 \\
(71.80)\end{array}$ & $\begin{array}{l}127.73 \\
(73.54)\end{array}$ & $\begin{array}{l}111.23 \\
(66.99)\end{array}$ & $\begin{array}{l}126.12 \\
(54.65)\end{array}$ & $\begin{array}{l}110.51 \\
(67.44)\end{array}$ \\
\hline Poverty Rate & $\begin{array}{l}0.46 \\
(0.50)\end{array}$ & $\begin{array}{l}0.45 \\
(0.50)\end{array}$ & $\begin{array}{l}0.46 \\
(0.50)\end{array}$ & $\begin{array}{l}0.57 \\
(0.49)\end{array}$ & $\begin{array}{l}0.47 \\
(0.50)\end{array}$ & $\begin{array}{l}0.58 \\
(0.49)\end{array}$ \\
\hline \multicolumn{7}{|c|}{ Demographic characteristics of households } \\
\hline Proportion aged 15 or below & $\begin{array}{l}0.32 \\
(0.21)\end{array}$ & $\begin{array}{l}0.31 \\
(0.22)\end{array}$ & $\begin{array}{l}0.33 \\
(0.21)\end{array}$ & $\begin{array}{l}0.18 \\
(0.20)\end{array}$ & $\begin{array}{l}0.22 \\
(0.22)\end{array}$ & $\begin{array}{l}0.18 \\
(0.20)\end{array}$ \\
\hline Proportion aged $16-25$ & $\begin{array}{l}0.21 \\
(0.20)\end{array}$ & $\begin{array}{l}0.21 \\
(0.21)\end{array}$ & $\begin{array}{l}0.22 \\
(0.20)\end{array}$ & $\begin{array}{l}0.16 \\
(0.21)\end{array}$ & $\begin{array}{l}0.10 \\
(0.16)\end{array}$ & $\begin{array}{l}0.16 \\
(0.21)\end{array}$ \\
\hline Proportion aged 26-35 & $\begin{array}{l}0.14 \\
(0.17)\end{array}$ & $\begin{array}{l}0.14 \\
(0.16)\end{array}$ & $\begin{array}{l}0.14 \\
(0.17)\end{array}$ & $\begin{array}{l}0.13 \\
(0.20)\end{array}$ & $\begin{array}{l}0.10 \\
(0.17)\end{array}$ & $\begin{array}{l}0.13 \\
(0.20)\end{array}$ \\
\hline Proportion aged $36-45$ & $\begin{array}{l}0.11 \\
(0.14)\end{array}$ & $\begin{array}{l}0.10 \\
(0.14)\end{array}$ & $\begin{array}{l}0.11 \\
(0.14)\end{array}$ & $\begin{array}{l}0.13 \\
(0.20)\end{array}$ & $\begin{array}{l}0.15 \\
(0.20)\end{array}$ & $\begin{array}{l}0.13 \\
(0.20)\end{array}$ \\
\hline Proportion & $\begin{array}{l}0.10 \\
(0.15)\end{array}$ & $\begin{array}{l}0.10 \\
(0.15)\end{array}$ & $\begin{array}{l}0.10 \\
(0.14)\end{array}$ & $\begin{array}{l}0.15 \\
(0.22)\end{array}$ & $\begin{array}{l}0.10 \\
(0.29)\end{array}$ & $\begin{array}{l}0.15 \\
(0.21)\end{array}$ \\
\hline Proportion aged $56-65$ & $\begin{array}{l}0.07 \\
(0.15)\end{array}$ & $\begin{array}{l}0.09 \\
(0.17)\end{array}$ & $\begin{array}{l}0.06 \\
(0.12)\end{array}$ & $\begin{array}{l}0.16 \\
(0.28)\end{array}$ & $\begin{array}{l}0.22 \\
(0.36)\end{array}$ & $\begin{array}{l}0.15 \\
(0.28)\end{array}$ \\
\hline Proportion aged above 65 & $\begin{array}{l}0.04 \\
(0.12)\end{array}$ & $\begin{array}{l}0.06 \\
(0.14)\end{array}$ & $\begin{array}{l}0.04 \\
(0.09)\end{array}$ & $\begin{array}{l}0.10 \\
(0.23)\end{array}$ & $\begin{array}{l}0.11 \\
(0.20)\end{array}$ & $\begin{array}{l}0.10 \\
(0.24)\end{array}$ \\
\hline Average age of adults & $\begin{array}{l}37.42 \\
(7.88)\end{array}$ & $\begin{array}{l}38.20 \\
(8.62)\end{array}$ & $\begin{array}{l}36.81 \\
(7.20)\end{array}$ & $\begin{array}{l}43.65 \\
(11.53)\end{array}$ & $\begin{array}{l}45.99 \\
(11.95)\end{array}$ & $\begin{array}{l}43.54 \\
(11.50)\end{array}$ \\
\hline Proportion of adults who are male & $\begin{array}{l}0.48 \\
(0.15)\end{array}$ & $\begin{array}{l}0.46 \\
(0.16)\end{array}$ & $\begin{array}{l}0.49 \\
(0.14)\end{array}$ & $\begin{array}{l}0.48 \\
(0.20)\end{array}$ & $\begin{array}{l}0.41 \\
(0.25)\end{array}$ & $\begin{array}{l}0.49 \\
(0.20)\end{array}$ \\
\hline Households with male head & $\begin{array}{l}0.93 \\
(0.25)\end{array}$ & $\begin{array}{l}0.91 \\
(0.29)\end{array}$ & $\begin{array}{l}0.96 \\
(0.21)\end{array}$ & $\begin{array}{l}0.87 \\
(0.34)\end{array}$ & $\begin{array}{l}0.71 \\
(0.46)\end{array}$ & $\begin{array}{l}0.88 \\
(0.33)\end{array}$ \\
\hline \multicolumn{7}{|l|}{ Education of adults } \\
\hline $\begin{array}{l}\text { Proportion with no formal } \\
\text { education }\end{array}$ & $\begin{array}{l}0.09 \\
(0.16)\end{array}$ & $\begin{array}{l}0.10 \\
(0.17)\end{array}$ & $\begin{array}{l}0.08 \\
(0.15)\end{array}$ & $\begin{array}{l}0.03 \\
(0.12)\end{array}$ & $\begin{array}{l}0.00 \\
(0.00)\end{array}$ & $\begin{array}{l}0.03 \\
(0.13)\end{array}$ \\
\hline Proportion with primary education & $\begin{array}{l}0.45 \\
(0.30)\end{array}$ & $\begin{array}{l}0.47 \\
(0.30)\end{array}$ & $\begin{array}{l}0.43 \\
(0.30)\end{array}$ & $\begin{array}{l}0.31 \\
(0.34)\end{array}$ & $\begin{array}{l}0.47 \\
(0.37)\end{array}$ & $\begin{array}{l}0.30 \\
(0.34)\end{array}$ \\
\hline $\begin{array}{l}\text { Proportion with secondary } \\
\text { education }\end{array}$ & $\begin{array}{l}0.29 \\
(0.26)\end{array}$ & $\begin{array}{l}0.27 \\
(0.26)\end{array}$ & $\begin{array}{l}0.31 \\
(0.27)\end{array}$ & $\begin{array}{l}0.51 \\
(0.35)\end{array}$ & $\begin{array}{l}0.33 \\
(0.33)\end{array}$ & $\begin{array}{l}0.52 \\
(0.35)\end{array}$ \\
\hline Proportion with vocational training & $\begin{array}{l}0.08 \\
(0.17)\end{array}$ & $\begin{array}{l}0.08 \\
(0.17)\end{array}$ & $\begin{array}{l}0.08 \\
(0.17)\end{array}$ & $\begin{array}{l}0.07 \\
(0.18)\end{array}$ & $\begin{array}{l}0.09 \\
(0.24)\end{array}$ & $\begin{array}{l}0.07 \\
(0.18)\end{array}$ \\
\hline Pro & $\begin{array}{l}0.09 \\
(0.19)\end{array}$ & $\begin{array}{l}0.07 \\
(0.18)\end{array}$ & $\begin{array}{l}0.10 \\
(0.21)\end{array}$ & $\begin{array}{l}0.08 \\
(0.20)\end{array}$ & $\begin{array}{l}0.11 \\
(0.30)\end{array}$ & $\begin{array}{l}0.08 \\
(0.19)\end{array}$ \\
\hline
\end{tabular}


Table 4 continued

\begin{tabular}{llllll}
\multicolumn{3}{c}{ Albanians } & \multicolumn{3}{c}{ Serbs } \\
All & Yes & No & All & Yes & No \\
& & & & & \\
16.20 & 13.54 & 18.27 & 20.64 & 13.70 & 20.98 \\
$(13.03)$ & $(12.30)$ & $(13.21)$ & $(18.32)$ & $(19.22)$ & $(18.21)$ \\
0.41 & 0.36 & 0.45 & 0.47 & 0.32 & 0.47 \\
$(0.29)$ & $(0.29)$ & $(0.28)$ & $(0.38)$ & $(0.42)$ & $(0.38)$ \\
0.65 & 0.57 & 0.72 & 0.61 & 0.38 & 0.62 \\
$(0.48)$ & $(0.49)$ & $(0.45)$ & $(0.49)$ & $(0.49)$ & $(0.48)$ \\
0.27 & 0.25 & 0.28 & 0.34 & 0.25 & 0.34 \\
$(0.28)$ & $(0.28)$ & $(0.29)$ & $(0.40)$ & $(0.39)$ & $(0.40)$
\end{tabular}

\section{Labor market characteristics}

Average number of weeks of labor

per household member per year

Proportion of working adults

Household with working head

Proportion of households with

members working in family farms

$\&$ businesses

\section{Wealth/Assets}

Acreage of land household owns

$$
0.07
$$

0.07

0.06

0.12

0.08

0.12

(000)

$(0.10)$

$(0.09)$

$(0.10)$

$(0.62)$

(0.14)

$(0.63)$

Value of animals household owns

0.56

0.61

0.52

0.46

0.24

0.47

(000 DM)

$(0.78)$

$(0.80)$

$(0.76)$

$(0.75)$

$(0.48)$

$(0.76)$

\section{Transfers}

Households at least one of whose

members has a disability card

Geographic characteristics

$\begin{array}{lllllll}\text { Households that migrated from } & 0.76 & 0.81 & 0.72 & 0.09 & 0.16 & 0.09 \\ \text { another region } & (0.43) & (0.40) & (0.45) & (0.29) & (0.37) & (0.28) \\ \text { Urban households } & 0.28 & 0.22 & 0.32 & 0.42 & 0.36 & 0.42 \\ & (0.40) & (0.37) & (0.41) & (0.49) & (0.48) & (0.49) \\ \text { Social network } & & & & & & \\ \text { Head resided abroad prior to } & 0.04 & 0.03 & 0.04 & 0.01 & 0.00 & 0.01 \\ \text { conflict } & (0.19) & (0.18) & (0.19) & (0.08) & (0.00) & (0.09) \\ \text { Child resides abroad } & 0.22 & 0.36 & 0.11 & 0.26 & 0.11 & 0.27 \\ & (0.41) & (0.48) & (0.32) & (0.44) & (0.31) & (0.44) \\ \text { Number of households } & 2101 & 924 & 1177 & 416 & 19 & 397\end{array}$

Source: LSMS and the authors' own calculation.

Notes: The figures within the parentheses are standard deviations. 
Table 5

Decomposing the Difference in Per-Capita Expenditure of $\mathbf{- 0 . 1 4 7} \log$ points between Serbs and Albanians

\begin{tabular}{|c|c|c|c|c|}
\hline & \multicolumn{2}{|c|}{$\begin{array}{l}\text { Characteristics } \\
\text { Effect }\end{array}$} & \multicolumn{2}{|c|}{$\begin{array}{l}\text { Coefficients } \\
\text { Effect }\end{array}$} \\
\hline & Estimate & Share & Estimate & Share \\
\hline Aggregate Effect & 0.077 & -51.79 & $-0.224 * * *$ & 151.79 \\
\hline Aggregate Effect Without Constants & 0.077 & -51.79 & 0.419 & -283.73 \\
\hline Constant & & & $-0.644 * *$ & 435.52 \\
\hline Demographic characteristics of households & 0.029 & -19.54 & 0.272 & -183.95 \\
\hline Proportion aged 15 or below & $0.051^{*}$ & -34.28 & 0.096 & -65.23 \\
\hline Proportion aged 16-25 & 0.009 & -6.13 & 0.009 & -6.00 \\
\hline Proportion aged $36-45$ & 0.002 & -1.64 & 0.011 & -7.55 \\
\hline Proportion aged $46-55$ & -0.004 & 2.71 & -0.018 & 12.51 \\
\hline Proportion aged 56-65 & -0.014 & 9.63 & -0.020 & 13.36 \\
\hline Proportion aged above 65 & -0.011 & 7.77 & -0.004 & 2.52 \\
\hline Proportion of adults who are male & 0.001 & -0.75 & 0.028 & -18.75 \\
\hline Proportion with male head & -0.005 & 3.16 & $0.170 *$ & -114.81 \\
\hline Education & $0.128 * * *$ & -86.46 & 0.236 & -159.37 \\
\hline Proportion of adults with primary education & $-0.044 *$ & 29.61 & 0.055 & -36.89 \\
\hline Proportion of adults with secondary education & $0.192 * * *$ & -129.71 & 0.094 & -63.60 \\
\hline Proportion of adults with vocational training & $-0.006 * * *$ & 4.07 & 0.027 & -18.34 \\
\hline Proportion of adults with tertiary education & $-0.014 * * *$ & 9.57 & $0.060 * * *$ & -40.53 \\
\hline Labor market characteristics & 0.009 & -5.93 & $-0.128 * *$ & 86.68 \\
\hline $\begin{array}{l}\text { Average number of weeks of labor per household } \\
\text { member per year }\end{array}$ & 0.012 & -8.11 & -0.021 & 13.95 \\
\hline Proportion of working adults & -0.011 & 7.53 & -0.114 & 77.37 \\
\hline Household with working head & -0.002 & 1.24 & -0.020 & 13.30 \\
\hline $\begin{array}{l}\text { Proportion of households with members working } \\
\text { in family farms \& businesses }\end{array}$ & 0.010 & -6.58 & 0.027 & -17.94 \\
\hline Wealth/Assets & -0.004 & 2.54 & -0.012 & 7.85 \\
\hline Acreage of land household owns $(000)$ & 0.001 & -0.38 & -0.013 & 8.57 \\
\hline Value of animals household owns (000 DM) & -0.004 & 2.92 & 0.001 & -0.72 \\
\hline Transfers & $-0.131 * * *$ & 88.43 & $0.089^{*}$ & -60.15 \\
\hline $\begin{array}{l}\text { Proportion of households at least one of whose } \\
\text { members has a disability card }\end{array}$ & 0.000 & -0.02 & -0.012 & 7.95 \\
\hline $\begin{array}{l}\text { Proportion of household at least one of whose } \\
\text { members receive private transfers }\end{array}$ & $-0.131 * * *$ & 88.45 & $0.101 * *$ & -68.11 \\
\hline Geographic Characteristics & 0.066 & -44.36 & -0.057 & 38.85 \\
\hline Households that migrated from another region & 0.058 & -39.40 & -0.067 & 45.22 \\
\hline Urban households & 0.007 & -4.96 & 0.009 & -6.37 \\
\hline Sector of Employment & $-0.020 * *$ & 13.52 & 0.020 & -13.63 \\
\hline
\end{tabular}


Notes:

i. Share refers to the ratio of the contribution of each factor to the overall differences in per-capita expenditures of $-0.148 \log$ points between Serbs and Albanians; it is expressed as a percentage of this difference.

ii. The symbols $*, * *$ and $* * *$ indicate significance at the $10 \%, 5 \%$ and $1 \%$ levels, respectively. 


\section{Acknowledgement Note}

Earlier versions of this paper were presented at the conference entitled "75 Years of Development Research" at Cornell University, Ithaca NY, USA, May 2004, at the conference entitled "Making Peace Work," at WIDER, Helsinki, Finland, June 2004, and at IZA, Bonn, Germany. The authors thank two anonymous referees and the Editor for their helpful comments.

\section{Endnotes}

1.Throughout this paper per-capita expenditure is measured as the per-adult-equivalent household expenditure per month.

2.The impact of landownership on the measurement of poverty is ambiguous. Buvinic and Gupta (2001) provide evidence suggesting that the degree of poverty acuteness, or consumption deprivation, among female-headed households may be less than expected due to self-consumption of production from the family land holdings. In contrast, Moene (1992) argues that, under certain circumstances, the redistribution of land from large landholders to landless laborers increases poverty.

3.The survey over-samples Serbian households. In a sample containing only these two ethnic groups in Kosovo, Serbs should account for $7.4 \%$ and Albanians $92.6 \%$ of the observations. In our data, $83 \%$ of the households are Albanians and the rest are Serbs. We use weights to account for this difference between the population and the sample.

4.The data were used to construct monthly and daily expenditure per adult equivalence for each household. This estimate was compared with the poverty line of 3.499DM per adult per day given in World Bank (2001). Using this poverty line, our data show that $56.7 \%$ of Serbian households and $45.9 \%$ of Albanian households live in poverty.

5.We thank an anonymous referee for suggesting that this educational difference may have occurred because, after Milosevic-led Serbia circumscribed Kosovo's autonomy, the Albanian 
political movement created an entirely new educational structure that was not accepted formally by the Serbian authorities. Many Albanian primary and secondary school students went to informal private schools rather than to the official schools. The Albanian community objected to the new curriculum in the official schools not the language of instruction, which remained Albanian.

6.Researchers often take the employment status of the household head as a proxy for the extent of labor market participation of household members. Our data confirm the expected positive correlation between the employment status of household heads and that of working-age adults in general. Although $72 \%$ of the heads of non-poor Albanian households and $66 \%$ of the heads of non-poor Serbian households are employed, the corresponding figure for heads of both poor Albanian and poor Serbian households is $57 \%$.

7.Given the turbulent history of Kosovo, identifying the reason for Serbian households owning more land, on average, than Albanian households is difficult. Anecdotal evidence is sometimes used to argue that the land and the property of Albanian households were appropriated by the Milosevic government and some of these assets could have been redistributed to Serbian households. Some evidence suggests that, during the Milosevic regime, the Serbian military machine was involved in a systematic campaign of the destruction of property owned by Kosovo Albanian civilians (http://www.un.org/icty/indictment/english/mil-ai010629e.htm). However, the informational value of this anecdotal evidence is questionable.

8. We thank an anonymous referee for suggesting this explanation.

9.The Oaxaca decomposition was introduced initially to study racial or gender wage differentials using regression analysis to generate the characteristics and coefficients effects. However, this approach can be applied to studying the differences of any continuous variables pertaining to 
individuals, households, or firms.

10. The methodology for hypothesis testing with the decomposition equations is found in Yun (2005), which extends Oaxaca and Ransom (1998).

11. Blinder (1973) gives a similar interpretation. However, Oaxaca and Ransom (1999) caution that the coefficients effect will vary depending on which dummy variables are omitted. In order to check the robustness of our decomposition results, we experimented by omitting alternative variables and found that the decomposition results did not change substantially. 